\section{THE SCIENCE COLLECTIONS AT SOUTH}

\section{KENSINGTON}

THE following is the Report of the Committee appointed by the Treasury to inquire into the Science Collections at South Kensington :- -

I. Our originai instructions are contained in the Treasury $M$ inute of the Igth February 1889 , which will be found in the Appendix (No. I). Upon consideration, we found that some amplification of these instructions were necessary, and we accordingly communicated to Government the resolution which is printed in the Appendix (No. 2). In reply to this resolution we received a letter from the Treasury under date of the $23 \mathrm{rd}$ March, Appendix (No. 3).

2. After some preliminary deliberation, and an inspection of the collections which form the subject matter of our inquiries, we proceeded to take evidence from representatives of the Science and Art Department and others who had been practically concerned in the formation and arrangement of these collections; and, during our inquiries, we have again inspected the several branches of the Museum in company with professor of the Normal School of Science and others specially conversant with the contents of each; we have also been furnished with detailed catalogues of the collections. By these means we trust that we have secured an acquaintance with the contents of the science collections sufficiently exact for the purpose of our present inquiry.

3. It may be convenient that we should recapitulate the different collections with which we have had to deal, noticing at the same time the manner in which they are at present housed. In these respects, the changes since Sir Frederick Bramwell's Committee reported have been not inconsiderable.

The collections have been classified by the Department (January I888) under two main divisions :-

I. Instruction and Research.

II. Industrial Applications.

Division I.-The collection of Scientific Instruments ano Appliances for science teaching occupies 6325 square feet on the ground floor and 15,840 square feet on the upper floor (in all 22,165 square feet) of the Western Galleries. ${ }^{1}$

It is grouped by the Department under the following heads, corresponding in the main with the arrangement of the Science Directory.

A.-Mechanics and Mathematics.

B.--Physics,

C.-Chemistry, Metallurgy, and Principles of Agriculture.

D. - Biology.

F.--Geology, Mineralogy, and Mining.

F.-Navigation, Nautical Astronomy, and Physiography.

The collections illustrative of Mining are, however, housed in the Geological Museum in Jermyn Street, in connection with the Royal School of Mines. These we have not examined or considered.

Division II.-Industrial Applications.

(a) The collection of Machinery and Inventions (including the selected specimens from the old Patent Museum, and also some few illustrations of metallurgical operations) occupies 18,476 square feet on the ground floor of the "Southern Galleries." 2

(b) The collection illustrative of Naval Architecture and Machinery occupies 15,374 square fect in all on the upper and ground floors of the "Southern Galleries," the machinery being on the ground floor.

(c) The Fish Culture collections and some miscellaneous objects occupy 5630 square feet in a wing at the west end of the "Southern Galleries."

4. In addition to these branches of our subject we should, in order to complete the list of scientific collections, mention the two following, which lie beyond the terms of our reference :-

(i.) The Educational Library of Science. This is now placed in the Museum, to the east of Exhibition Road, in connection with the Art and General Library.

(ii.) The collection ; of Food and Animal Products, formerly at South Kensington. These are now housed in the Bethnal Green Branch Museum.

It may be convenient to add that about 16,000 square feet on the two floors of the eastern end of the Southern Galleries

${ }^{I}$ The Western Gallerics are those aljoining Quen's Gizte and north of the new Imperial Institute $R$ oad.

The Suthern Galleries are those extending from Fxhibition Road to Queen's Gate to the south of the new Imperial Institute Road. (formerly the National Portrait Gallery) ase now occupied by $i$ collection of modern industrial products, furniture, and ornaments, removed thither from Bethnal Green, which belongs to the Art division of the Museum, and has no connection with the Science collections upon which it is our duty to report. Further, about 9200 square feet on the ground floor of the Western Galleries are used only for examination rooms.

5. It will be observed that in our enumeration of the branches of the Science Collections as at present existing, we have made no reference to two branches mentioned in the Report of Sir F. Bramwell's Committee :-

(a) The Educational Collection.

(b) The Structural Collection.

For these sections spaces of 7000 square feet and of 15,000 rising to 25,000 square feet respectively, were demanded by the Committees whose recommendations were adopted in that Report.

These sections have been suppressed for reasons given by General Donnelly, the articles of which they were composed having been returned to the lenders or otherwise disposed of. It was probably the aspect of these collections which, upon a superficial view of them, led to the severe strictures sometimes passed on the contents of the Southern Galleries.

As regards these two sections, we may here say that in our opinion the necessity for the exhibition of school furniture and fittings, such as are required for schools receiving grants under the Elementary Education Acts, no longer exists; but (under proper limitation) a series of diagrams and models of the best forms of construction and a collection of specimens of material, specially designed for scientific and technical education, might with advantage be exhibited in connection with the subject of mechanics as taught in the Norman School, and with that subject and with building construction as taught in science classes, and with the general collection of applied science. Such a collection should be strictly technical in character; otherwise there would be a risk of indefinite extension in this department.

6. The order in which we have described the collections in our third paragraph follows the arrangement adopted by the Science and Art Department in Tanuary 1888, and agrees with that suggested in paragraph 26 of Sir F. Bramwell's Report, where the "instruction given in the Normal School of Science" coupled with "the teaching of science generally throughout the United Kingdom," precedes " the acquisition of other objects in the interest of science or of the arts."

It is indeed evident that the collections in the Western Galleries, containing instruments and appliances indispensable for the teaching of science, are more closely connected with the work of the Normal School and the science classes in connection with the Department than the machinery, to which, however, some of the professors refer by way of illustration in their lectures; and the machinery is more closely connected with the Normal School and science classes than are the ship models, which at present are not used at all for the school; whilst the fish collection serves no direct educational purpose at all. We learn from the Treasury Letter of March 23 that the view as to the object of these collections expressed in paragraph 26 of Sir F. Bramwell's Report has in substance been adopted by Government, with the qualification that "the teaching of science generally" must be subject to "reasonable regulations."

Prof. Huxley, who, in one capacity or another, has had a very large share in the formation of these collections, maintains that the connection of the cullections with the Normal School of Science is "accessory and accidental," the essential object of them being, firstly, "to facilitate practical instruction in science, particularly in the teaching in the science classes connected with the Department, by enabling teachers to acquaint themselves with the various apparatus, models, and specimens which are indispensable to proper scientific instruction, or which have been found especially useful in such instruction, and in original investigation," and, secondly, "the preservation of apparatus and models which possess historical interest as marking stages either in the progress of discovery or in that of the application of scientific principles to art and industry.'

Without attempting to determine the relative value of such collections as regarcled from different points of view, we would state that in our opinion their direct educational bearing does not afford an adequate test of their value and importance.

7. We procecd to consider seriatim the several sections of the collection, beginning with the "Appliances for Instruction and 
Research" now in the Western Galleries. For this section, which now occupies a little over 22,000 square feet, the co.n. mittee of professors, whose report was adopted by Sir F. Bramwell and his collengues, estimated that 37,000 square feet were required, with an addition of 3,000 square feet in the next ten years, i.e. nearly duuble the area at present available. The space now provided is well filled but hardly overcrowded; the objects exhibited are, speaking generally, either of historical interest as illustrative of the development of scientific discovery, or representing the latest and most improved forms of scientific instruments and appliances. The collection is clearly of great use to the students in the Normal School, the professors of which draw upon it largely for illustrations of their lectures, or bring their classes into the galleries when that course is more cozvenient; and these remarks apply to the historical side of the collection almost as much as to its more immediately practical portions. It is of no less use to such of the teachers and students in science schools throughout the country (which receive grants from the Science and Art Department) as have opportunities of visiting it, whether singly or in organized classes. A special feature in the collection is the series of appliances for the teaching of science which it contains, sometimes systematically arranged ready for class use, sometimes shown as a group of similar objects made by different makers, with prices attached. We think that these samples (as they may be called) require very careful administrative watching in order to keep the selection exhibited up to the latest date and the best quality. For such specimens the Department has, especially in the early stages of the collections, been largely indebted to the assistance of private firms; for whom proper consideration must therefore be shown. These samples are doubtless of service to teachers, especially in the present comparatively undeveloped condition of elementary scientific teaching in this country; and the space occupied by them (mostly in wall cases) need not be large.

The collections now under consideration appear to have bcen on the whole carefully watcher by a committee of professors in the Normal School, who, under the exigencies of a limited space, have eliminated from them almost all objects of an obsolete character. Little further weeling is possible in them as they now stand, except perhaps in the case of some of the samples described above. Turning to the other side of the question, the complaints of want of space do not appear to be very serious; and the future development of such collections can, we think, be met in part, but not altogether, by the elimination of objects which, appropriate and necessary to-day, will become obs lete in the inevitable progress of scientific knowledge aud procedure. We say, "not altogether," because there ought to be retained a limited number of objects illustrating the historical development of the more important implements of scientific research; more over, some natural increase must be contemplated arising from the introduction of new methods of scientific investigation. Wall space is all that is required for the exhibition of diagrams, which can often be usefully employed in lieu or in aid of actual objects or instruments.

The need for the exhibition of the appliances for elementary science classes may be expected to diminish as the organization of scientific education improves, in the same way as the universal extension of primary schools has removed the necessity for such an exhibition of school desks and fittings as formerly existed in this Museum.

Included in the 40,000 square feet provided for by Sir F. Bramwell's committee are 4000 square feet for "agriculture." At present only a very small collection exists in connection with this subject. Lectures are from time to time delivered at the Normal Sthool, on the principles of agriculture, and the Department holds examinations in the same subject. But it is obvious that for the portion: of this subject in which instruction con usefully be given in lecture-rooms, the ilinstrative collections required nced occupy only a very modera'e amount of space. Any complete cullection of objects illustrative of the study of all branches of agriculture w suld require a space at South Kensington far larger than could be allotted to a mere branch of a Science Museum. The principal agricultural implements should be represented by models in the department of Machinery and Inventions; and provision seems to have been made for this purpose in the scheme for that department, to which we will subsequently refer.

The Western Gal eries at present in use are fairly satisfactory as regards construction and lighting, and ailow their nominal area and wall space to be utilized to the full extent of their capacity. They are, however, inconveniently situated as regards both the Normal School and the rest of the Museum, and we have little doubt that a building giving an equal accommodation could be provided at a cost less than the capitalized value of the rent ( $£ 2000$ per annum) at present paid for them.

On the whole, we are of opinion that, having regard to the financial exigencies which must always be present to those intrusted with the expenditure of public funds, a moderate increase on the present space should, subject to one important proviso, suffice, for some time to come, for the needs of the Normal School and other requirements of this section.

The proviso to which we refer is, that there should be a well organized system of management of the collection. We will revert hereafter to this point, which, in our judgment, affords the key to the whole question now before us.

8. Passing to the section devoted to Machinery and Inventions, we have to observe that this is of the nature of a technological museum rather than of a collection for the special benefit of the Normal School, or of the Science Classes connected with the Department. It is, however, to be observed that the Professor of Mechanics attaches great value to this collection for the purposes of his teaching; and that the objects used as illustrations by the Professor of Metallurgy (so far as he does not use diagrams) are practically included in this division of the Museum. Regarded from a broad point of view, the value and importance of this section must be admitted; and we approve of the policy which has been adopted by the Department ir recent years, of developing it at the expense of less important collections. In pursuance of this policy the area of this section has increased from I I, O00 to over I8, 000 square feet, now occupied to nearly its full capacity. This is still very far short of the space of 45,000 increasing to 60,000 square feet aclopted by Sir F. Bramwell's committee, and even of the more moderate demand of 40,000 square feet put forward by Mr. E. A. Cowper in his evidence before us, and based on carefully-detailed calculations. That gentleman has devoted a great amount of time and trouble to this collection, which bears the mark of his patriotic labours in the evident cndeavour to utilize the available space to the best advantage. There are a few objects, but only a few, in this collection which could properly be eliminated; but we consider that care should be taken not to acquire or receive full-sized machines where models can be made to serve the same purposes, and also to avoid unnecessary multiplication of parts in either model or machine. For example, two or three rows of bobbins, \&c., on a spinning frame show as completely the principles on which a machine is constructed as would a complete series, such as is to be found in actual use. Inferior or obsolete examples must be eliminated as better or more recent specimens are obtained, subject only to the retention of a few typical illustrations of historical development. Moreover, the development of the collection must inevitably be gradual, if properly carried out, as the right objects cannot be obtained off-hand, and the temptation to obtain or accept inferior examples should be avoided in every possible way. Even with these restrictions, we agree with Mr. Cowper that ultimate, if not immediate, provision of a maximum space of 40,000 square feet should be made for this branch of the Musetm; and we believe that, under well. organized and efficient management such as we have already pronounced essential, this space, if provided by means of suitable buildings, ought to suffice to contain a technological collection worthy of a great manufact uring country. As a temporary measure, space might be found for the expansion of this section by the removal of the deco ative objects which occupy the eastern end of the ground floor of the Southern Galleries.

9. Naval Coilictions. - Under this head are included complete models of vessels of various kinds, actual or proposed, forming an historical series, and mostly on loan; models illustrative of naval construction; and models of marine machinery, many of historic interest. In regard to this section of the Museum, we have had to consider the very debatable question of the suitability of South Kensington as a site for a marine collection. Though classes are examined by the Department in naval construction, no provision is at present made for teaching the subject in this locality. It is right, however, to say that "summer classes" in this subject are contemplated ; and a class is intended to be held next autumn. It will be remembered that the School of Naval Architecture (in connection with which this collection was originally formed) has beer: removed to Greenwich, and has assumed a more prominently military character. It is not easy at first sight to regard the west end of London as 
the most convenient centre for those interested in ship construction, especially considering the small amount of ship.building operations now conducted on the Thames. But it has been shown that there is a very strong sentiment among those interested in shipping in favour of the retention of the ship models in their present home, and the following are some of the practical reasons given in support of this view, by the Institute of Naval Architects and others :-

(I) The shipping companies and other owners of the large ornamental models have, it is said, declined to lend their property for permanent exhibition elsewhere than at South Kensington.

(2) The naval collections are closely connected with the Machinery and Inventions Section of the Museum.

(3) Being at South Kensington, the departmental system of circulation can, it is said, be applied to them.

This latter remark only applies in practice to a small portion of the collection, viz. the models, \&c., illustrative of the details of ship construction. The large models of ships do not belong to the Department, and in any case are too large and too valuable to be sent round, under the plea of some slight educational utility, to local schools of elementary science; though, under special circumstances, some of them have been lent by their owners to Exhibitions in the provinces, or even at Paris.

On the whole, we have arrived at the conclusion that it would be practically impossible to reconcile public opinion to the removal of thi- collection elsewhere, and that space must therefore be provided for it at South Kensington.

For this collection 10,500 square feet were demanded at once by the committee referred to in Sir F. Bramwell's Report, with an increase of $\mathrm{IO}, 000$ square feet. The space at present occupied is 15,374 square feet, or three-fourths of the maximum desired by the special committee. We consider that the present space should suffice, under proper administration, for an adequate exposition of the methods and results of the very important national industry of shipbuilding. In connection with this conclusion we would observe that, in our opinion-

(I) A certain number of the objects now exhibited could be eliminated "without injury to the value or representative character of the collections" ; and the fact that so much of the space is occupied by large ornamental models of ships, many of them on loan, would facilitate such elimination, when required for the introduction of new examples.

(2) Having regard to the fine historical and practical collection of war ships which exists at Greenwich, and is readily accessible to the gereral public, the portion of the South Kensington collection which relates to ships of war should be reduced to a minimum. It now occupies twenty pages of the catalogue, in which fifty-three numbers are described.

(3) The additions to the collection, other than in substitution for objects eliminated, should mainly consist of diagrams or small models of parts of ships or machinery, suited for practical in. struction in the art of ship-building. Such objects would be of use for circulation, and would not occupy any considerable amount of space.

Io. Fish Culture Coll ction. - No mention of this collection is made in the departmental scheme of classification dated January I888; and indeed it seems to bear little relation to the instruction given in the Normal School, to the teaching in science classes connected with the Department, or to the other sections of the Science Museum. Nor is South Kensington a situation naturally well adapted for fish-breeding operations. We beg to refer to the weighty opinion of Prof. Huxley as to the want of connection between this collection and its present surroundings, and the small educational or scientific value which it possesses in its present condition.

The greater part of this collection was bequeathed to the Department in 1880 by the late Mr. Frank Buckland, and a series of British fiches has, since that date, been presented to it by Dr. Day. This state of things would, however, in our opinion, hardly prevent the Department from transferring the collection to some other public institution. The Buckland Professorship, if the funds for its support are still available, might well be attached to the Marine Biological Laboratory at Plymouth, under regulations agreed to by the Science and Art Department. With the cons nt of the donors (when obtainable) some objects now forming part of this collection might find a place in the Natural Hist rry Museum ; and the remainder might be transferred to the Marine Biolog cal Association, and the Scotch Fishery Boatd, provided that tho:e bodies are able and willing to receive them. In any circumstances we are of opinion that there is no necessity for the collection being retained at South Kensington, and certainly no provision should be made for it in any building scheme there.

The large State barge and Venetian gondola now housed in the same galleries as the fish collection should also be removed.

II. Circulation. -With regard to that portion of the reference to us which relates to the system of circulation of objects in the provinces, we should explain that two different systems are comprised under that name. Under one of these, objects forming an integral part of the collections are lent by the Lepartment, for a limited period, to local museums. This in the case of the science collections is only done on a small scale ; the space so vacated is insignificant and cannot be utilized for other purposes, and it has therefore no practical bearing on the housing of the collections. The other kind of circulation is confined to science schools in connection with the Department. It consists in the loan of a typical set of objects and apparatus suitable for the teaching of one branch or another of science, such as chemistry, geology, \&c., with a view to improve the practical portion of local teaching. These circulating scts are never regularly exhibited at South Kensington, and therefore can only require a small a , ount of warehouse space for storage and arrangement. If the system of circulation grows, some additional warehouse space may be required, but no increase in the exhibition space would be involved.

12. The frequent mention in this Report of areas of exhibition space suffices to indicate how inevitably the question of housing the collections has been forced on our attention, notwithstanding that it does not explicitly form part of the terms of reference to us. In suggesting certain areas as, in our opinion, sufficient to meet the requirements of the case, we have assumed that the exhibition buildings should be well arranged, well lighted, and of a durable character. These requisites, however, are not fulfilled in the case of the Southern Galleries, the upper floor of which is, we are informed and believe, incapable of supporting considerable weights, so that collections of machinery cannot be placed in that portion of the building. It may also be obstrved that these galleries appear not to be well secured against fire. The rent of fI500 per annum is paid for the central block of this building, for the capitalized value of which sum a larger and more convenient building could apparently be erected. The present state of dispersion of the Museum involves extra expense in connection with the entrances, attendants, and police, and also increases the difficulty of an efficient superintendence by the superior officers in charge of the collections. We feel bound to call attention to these facts, which have been forcibly impressed on us by our observations on the spot as well as by the evidence we have received.

I3. We have already adverted to another matter which, though outside the literal terms of reference to us, is in our judgment of the very greatest importance in regard to the substance of the questions under consideration. We allude to the organization for the custody and management of the collection: At present this duty rests, under the Secretary, with the staff of the Director of the Museum, whose functions cover both the Art and the Science divisions, which differ widlely from one another. Attached, however, to each section of the Museum is a separate consultative committee; which, for the collections of scientific instruments and appliances, consists of the professors of the Normal School; while in the case of the other sections, the committees consist of gentlemen external to the Department. These committees can only recommend, not decide; and even when their recommendations are adopted, it does not follow that they can see that they are carried out. To committees of this kirud the task of refusing unsuitable loans is also peculiarly difficult and irksome; and there is also some danger of different committees causing overlapping between different portions of the collections, although we have no reason to think that this has as yet happened. On the other hand, there seems to be no syste of regular meetings of the committees at prescribed intervals (oftener than once a year), and regard being had to the composition of the committees, it is not to be expected that many members of them should be able to devote much time to this work, certainly not to the cletailed and continuous supervision which collections require. It must not be supposed that nothing has been gained from the existence of these committees; on the contrary, Mr. Cowper's work on the machine collections is an instance of the excellent service which individual members have rendered. But we consider the system defective in principle, 
apart from the personal qualities of those working under it ; and having formed a very decided opinion to this effect, we feel it our duty to call attention to the subject, in the interests of economy as well as of efficiency. The responsibility for the formation and supervision of these collections should certainly be of a more definite kind.

I4. Suggestions have been made that these collections might encroach on the field occupied by other scientific museums, With regard to this point we would call attention to the evidence of Prof. Judd as showing that a practical distinction can readily be drawn even at a point where two Museums closely approach one another in character.

I5. In conclusion, we may summarize the results of our inquiries by expressing the opinion that little, if any, space can be gained by weeding the existing collections, and that, subject to the reservations we have made as to effective organization and administration, and as to the character of the buildings to be assigned to the collections, an exhibition space of about 90,000 square feet should be provided without delay, and would suffice for the requirements of a creditable Science Museum, with adequate space for all the departments for which it appears at present necessary to provide. This space includes provision for a scientific structural collection on the lines indicated in para graph 5 of this Report, but does not include any provision for offices, warehouses, workshops, or other accessories to such a Museum.

JoIn Evans.

Francis Hervey.

RAYLEIGH.

B. Samuelson.

DOUglas Galton.

HENRY E. ROSCOE.

Stephen E. Spring Rice, Secretary. July 23,1889 .

\section{AN ITALIAN'S VIEW OF ENGLISH AGRICUIT URAL EDUCATION.}

$\mathrm{I}$ this lirochure, M. Italo Giglioli, Professor of Agricultural Chemistry at Portici, bas collected together a large amount of information upon agricultural education and agricultural research as carried out in the United Kingdom. A similar work upon the teaching of agriculture throughout Europe, by the same author, appeared last year. It is, however, noticeable that the volume on English agricultural education is three times the bulk of the earlier effort. M. Giglioli, as a foreigner, has considered our methods worthy of a much more detailed Re port than those of the Continent. This can only be regarded as a tribute to the excellence of English agriculture. We have heard a great deal of late upon the small amount of interest taken in agricultural education in England compared with Continental countries. An Italian Professor finds material for a portly volume on our systems of agricultural education and research, while he is able to compress his information upon the German, French, and Hungarian systems into a pamphlet of comparative thinness.

As a matter of fact, the Continental nations have been, at least in the past, ahead of us in these matters. The value of what is done in England rests rather upon the quality of our agriculture than upon our efforts to systematically teach it. Continental Professors of Agriculture find it as essential to visit England and to study English agriculture, as would an American Professor of History to visit Europe, or a Biblical student to visit Egypt and Palestine. The most noted breeds of cattle, sheep, and pigs, the best types of implement and machinery, the best artificial manures, the best systems of farming, have originated in England and Scotland, and hence the attention which is paid to agricultural research as prosecuted in Britain. So far. however, as the study of Agriculture is concerned, or painstaking and wide-spread investigation goes, the Continental nations are before us. It is not by any means certain that with these advantages they will excel us in the actual practice of agriculture. As a nation we are more adapted for doing than for study, and our progress is generally the result of pressure under competition, and the spontaneous adoption of the best practices, as they are publi:hed in the press. Our

I "Educazione agraria Britanica," relazione di Italo Giglioli. (Annali di Asricoltura, 1888.) improvements are less likely to emanate from technical schools than from the promulgation of new ideas, new processes, new material, new appliances, adopted by leading agriculturists, exhibited and reported upon.

M. Giglioli, like all Continental visitors to England, wonders with great admiration at the spontaneous character of our efforts Here, we succeed without Government help. There, both teaching and research often languish, although supported by huge grants, and are always discontentedly asking for more. "Il carattere più saliente che le distingue da tutte le altre scuole agrarie di Europa, è quello della loro completa autonomia, anche finanziaria. Esse non ricevono sussidio alcuno nè dal Governo, nè da provincie, nè da associazioni agrarie : vivono completamente sopro quello che quadagnano. Il contrasto tra le scuole inglesi e le continentali appare nel seguente quadro." The author then recounts, in tabular form, the cost to the student, and the incomparably greater cost to the State, of agricultural edlucation in Germany, France, and Italy; and, after showing that each student costs his State from 700 to 2500 lire, in addition to his own costs, he triumphantly writes "niente" in the column showing the cost to the State opposite the chief English agricultural schools.

The author's introductory remarks having been conclúded, the principal Societies engaged in agricultural education in these countries are next passed in review, and their methods, examina. tions, prizes, diplomas, are described. Such matter will no doubt be more interesting to Italian agriculturists than to ourselves. The number of these means of instruction is probably. greater than many Englishmen are aware of, and, as a point of considerable interest at the present time, we take the following list from M. Giglioli's book :-

The Royal Agricultural Society of England (an examining body). The Rothamsted Experimental Station (for research only).

The Royal Agricultural College, Cirencester (instructicnal and examining body).

The College of Agriculture, Downton (instructional and examining body).

The Colonial College, Hollesley Bay (instructional and examining).

The Department of Science and Art, South Kensington (instructional and examining).

The Darlington Chamber of Agriculture (Lecturer employed).

The Normal School of Science, South Kensington (Agricultural Professorship).

The University of Oxford (Sibthorpian Professorship).

Kirg's College, London (Agricultural Lectureship).

City of London College (Agricultural Lectureship).

The Worleston Dairy School, Cheshire.

The Sudbury Dairy School.

The Weald of Kent College of Agriculture.

The School of Agriculture, Aspatria, Cumberland.

The Agricultural School at Alvecote, Tamworth.

The agricultural instruction given at various County Schools.

The facilities for agricultural instruction in rural Elementary Schools.

The Forestry Department at Cooper's Hill.

The Surveyors' Institution, I2 Great George Street, Westminster (examining body).

The Royal Veterinary College, Camden Town.

The Brown Institute.

The Highland and Agricultural Society (examining body).

The Agricultural Department of the University of Edinburgh.

The Agricultural Department of the College of Science and Technology, Edinburgh.

Course of Agriculture at Glasgow Technical College.

The Agricultural Department in Aberdeen University.

The Royal Veterinary College, Edinburgh.

The New Veterinary College, Edinburgh.

The Veterinary College, Glasgow.

The Agricultural School at Templemoyle, Ireland.

The Royal Albert Institution, Glasnevin, Dublin.

The Dairy School for Females, Glasnevin.

The Munster Dairy School, near Cork.

Canon Bagot's Creameries, Ireland.

The Governmental agricultural instruction in Elementary Schools, Ireland.

The above Societies, Colleges, and Schools engaged in the work of agricultural education are all carefully described. The list might have been made longer, as M. Giglioli does not seem 